\title{
PERAN BUDAYA DALAM PEMEROLEHAN BAHASA ASING
}

\author{
Zelvia Liska Afriani ${ }^{1 凶}$ \\ ${ }^{1}$ Institut Agama Islam Negeri (IAIN) Bengkulu \\ 'zelvia@iainbengkulu.ac.id
}

\begin{abstract}
This study aims at examining the role of culture in learning English as a foreign language. Previous researchers explained that there is an intimate relationship between language and culture. It is obviously mentioned that when someone is willing to learn a language, he also needs to learn its culture so as to master it fully. Therefore, the researcher would like to investigate whether the teachers at school has understood and implemented cultural literacy in the language classroom or not. In this study, the researcher used a descriptive qualitative study and gathered the information needed from some English teachers in North Bengkulu. The result shows that the English teachers has been aware of the importance of cultural literacy in English language classroom since it can enhance students' communicative competence. There are some offered ideas that can be employed in introducing cultural literacy, such as using authentic materials, proverbs, role-play, students as cultural resources, ethnography study, and literature.
\end{abstract}

Keywords: foreign language, cultural literacy

Abstrak : Penelitian ini bertujuan untuk mengetahui peran budaya dalam pemerolehan bahasa Inggris sebagai bahasa asing. Para peneliti sebelumnya menjelaskan bahwa terdapat keterkaitan erat antara bahasa dan budaya, yaitu ketika seseorang ingin menguasai sebuah bahasa maka budaya dari bahasa tersebut juga harus dipelajari. Dalam hal ini, peneliti ingin mengetahui apakah para guru di sekolah sudah mengimplementasikannya di kelas dengan baik. Penelitian ini menggunakan metode deskriptif kualitatif. Subjek penelitian untuk mendapatkan informasi yang dibutuhkan adalah beberapa guru di wilayah Bengkulu Utara. Hasil penelitian menunjukkan bahwa guru sudah mulai menyadari pentingnya mengenalkan literasi budaya di dalam kelas bahasa terutama bahasa Inggris sebagai bahasa asing. Hal ini dikarenakan apabila ingin membuat peserta didik sukses dalam berkomunikasi dan berinteraksi, maka konten budaya juga harus diajarkan di dalam kelas melalui berbagai cara seperti penggunaan bahan otentik, amsal, permainan peran, siswa sebagai sumber budaya, studi etnografi, dan literatur.

Kata Kunci : bahasa asing, literasi budaya 
Volume 1, Nomor 2, Juli 2019

ISSN 2655-3031 (P), 2655-7851 (O)

\section{Pendahuluan}

Para ilmuan dan peneliti percaya bahwa budaya memegang peranan penting dalam mempelajari suatu bahasa. Keterkaitan antara budaya dan bahasa tidak dapat dipisahkan jika seseorang ingin menguasai sebuah bahasa. Secara sadar maupun tidak sadar, budaya juga akan mempengaruhi pikiran penutur bahasa. Hal ini dapat dilihat ketika bahasa yang digunakan untuk berkomunikasi sehari-hari terbukti dapat membentuk suatu budaya. Berkomunikasi dalam suatu kelompok sosial tidak hanya berbicara dan bertukar pikiran, tetapi juga belajar, berpikir, dan percaya pada cara interaksi yang ada dalam konteks budaya pada bahasa yang digunakan. Oleh karena itu, belajar bahasa tidak hanya melibatkan pengetahuan tentang bahasa, tetapi juga menyadari kepercayaan dan nilai-nilai yang membingkai bahasa agar sejalan dengan budaya.

Bahasa adalah media komunikasi yang mengekspresikan, mewujudkan, dan melambangkan realitas budaya. Bahasa dapat mencerminkan persepsi, perspektif, dan sikap seseorang terhadap dunia, bagaimana seseorang atau komunitas berbagi pengalaman, menciptakan makna, dan menempatkan serta menemukan identitas sosial mereka (Assemi, Saleh, Asayeshh, \& Janfaza, 2012). Berbagi dan menciptakan makna, artinya bahasa yang digunakan dapat dimengerti dan dikomunikasikan kepada anggota komunitas atau kelompok sosial, yang pada gilirannya membantu orang untuk mengidentifikasi suatu kelompok sebagai bagian dari dalam budaya dan membedakan orang luar dari kelompok sosial lainnya.

Budaya dapat didefinisikan sebagai suatu tatanan yang hidup pada sekelompok orang yang berkenaan dengan pandangan hidup, kepercayaan, adat istiadat, dan sistem politik yang diwarisi secara turun temurun dan dijaga keberadaannya. Spencer-oatey (2012) menyebutkan budaya terdiri atas karakteristik yang dimiliki suatu komunitas dari perilaku dan interaksi sosial, konstruksi kognitif, dan pemahaman afektif. Pola yang diperoleh melalui proses sosialisasi ini secara tidak disadari akan ditransmisikan ke generasi mendatang.

Keterkaitan antara budaya dan bahasa sangatlah erat karena keduanya saling mempengaruhi penutur bahasa dalam berkomunikasi dan berinteraksi. Giosa (2009) menjelaskan bahwa budaya dapat digambarkan sebagai dua sisi mata uang yaitu dari sisi humaniora dan ilmu sosial. Sisi humaniora mengacu pada kondisi bagaimana kelompok sosial mewakili diri mereka sendiri dan orang lain dalam proses produksi material, karya seni, sastra, lembaga sosial, atau artefak kehidupan sehari-hari. Sedangkan, sisi ilmu sosial mengacu pada perilaku, sikap dan kepercayaan, cara berpikir, serta perilaku yang dilakukan pada anggota kelompok di dalam komunitasnya. Dalam hal ini, sejarawan atau ilmuwan sosial tampaknya menjadi agen yang bertanggung jawab untuk mengajarkan budaya. Padahal, untuk bidang-bidang tertentu, budaya juga menjadi tanggung jawab guru bahasa untuk diajarkan kepada para peserta didik karena budaya memanifestasikan dirinya melalui bahasa.

Mempelajari sebuah bahasa tanpa mempelajari budayanya tampaknya tidak akurat dan tidak lengkap. Ada istilah khusus yang dikemukakan oleh Hirsch (1984) dalam kaitannya dengan pengajaran budaya, yaitu 'literasi budaya'. Istilah itu ditemukan ketika mengamati kehidupan Amerika yang dulunya buta huruf dan tidak memiliki kemampuan untuk memahami dan berpartisipasi dengan lancar dalam budaya sendiri ketika berkomunikasi satu sama lain. Tentunya, ini memberikan dampak bagi kehidupan sosial pada saat itu, seperti hilangnya makna komunikasi sehingga membuat keadaan masyarakat Amerika jatuh. Oleh karena itu, Hirsch menekankan bahwa anak-anak harus diperkenalkan dan diajarkan untuk melek budaya di dalam kelas sedini mungkin.

Anak-anak perlu memiliki latar belakang pengetahuan yang berkaitan 
Volume 1, Nomor 2, Juli 2019

ISSN 2655-3031 (P), 2655-7851 (O)

dengan budaya dalam mempelajari bahasa agar memahami bahan bacaan dan mampu mendapatkan informasi yang tepat. Dalam hal ini, tidak semua anak memiliki kesempatan untuk mendapatkan informasi baca tulis di luar sekolah. Oleh karena itu, ruang kelas berperan penting dalam memberikan informasi berharga yang dapat diperoleh dari guru.

Literasi budaya merupakan salah satu hal penting yang harus diperhatikan oleh para guru dalam proses belajar mengajar di kelas. Namun, dalam konteks pembelajaran bahasa asing seperti bahasa Inggris, poin ini menjadi masalah utama yang mungkin ditemukan peserta didik. Mereka tidak dapat menggunakan bahasa Inggris sebagai bahasa target secara efektif dan tepat dalam berkomunikasi karena tidak memiliki latar belakang pengetahuan tentang budaya bahasa target. Oleh karena itu, peran guru sangatlah penting untuk memperkenalkan budaya yang ada pada bahasa target ke siswa agar tidak menyebabkan kesalahpahaman atau bahkan kegagalan pragmatis dalam berkomunikasi dan berinteraksi.

Di Indonesia, bahasa Inggris sebagai bahasa asing sudah menjadi sebuah tuntutan untuk dikuasai secara fasih baik lisan maupun tulisan oleh peserta didik. Pada kurikulum pendidikan Indonesia, bahasa Inggris menjadi bahasa asing yang musti dipelajari di sekolah dari pendidikan tingkat dasar, menengah hingga atas. Bahasa Inggris menjadi salah satu mata pelajaran penting yang diajarkan oleh guru di dalam kelas. Oleh karena itu, guru bahasa asing dalam hal ini harus mengetahui bahwa ketika mengajar di dalam kelas bukan hanya tata bahasa, kosakata, kemampuan mendengar, berbicara, membaca, dan menulis yang diajarkan. Namun, ada hal-hal lain yang harus disadari yaitu menyelipkan kesadaran budaya (Cultural Awareness) kepada siswa. Kesadaran budaya adalah cara sesorang memahami perbedaan antara komunitas mereka dan orang lain yang berbeda negara dan latar belakang, terutama perbedaan dalam sikap dan nilai (Frank, 2013). Jika guru memberikan penjelasan ini kepada siswa, maka siswa dapat menempatkan dirinya di konteks budaya tersebut digunakan. Dengan demikian kesalahpahaman dalam berkomunikasi akan berkurang atau bahkan tidak terjadi.

Ada beberapa contoh situasi yang mungkin akan membuat peserta didik salah tafsir ketika berkomunikasi dalam bahasa Inggris dengan orang lain yang memiliki latar belakang budaya berbeda. Misalnya, dalam konteks budaya Indonesia, menanyakan umur seseorang adalah hal yang biasa dan wajar. Namun, hal tersebut tidak bisa kita tanyakan kepada orang luar Indonesia (orang Barat) karena dalam budaya mereka, hal tersebut merupakan privasi dan tidaklah sopan ketika pertanyaan itu dilontarkan. Sama halnya dengan menyapa seseorang yang belum terlalu dikenal atau bahkan baru dikenal dengan pertanyaan "Mau kemana?" agar terlihat ramah adalah hal yang lumrah dan sering dilakukan orang Indonesia ketika mereka bertemu di jalan atau di beberapa tempat. Tetapi, pertanyaan ini tidak pantas diucapkan dalam situasi budaya barat karena cenderung akan menerima penolakan.

Contoh lain yang bisa dilihat adalah dari segi penuturan nama. Pada budaya Barat memanggil nama orang yang lebih tua dengan nama mereka adalah hal yang lumrah. Misalnya seorang adik memanggil nama kakaknya George saja atau memanggil ayahnya dengan panggilan John tanpa dibubuhi pengalamatan seperti di Indonesia bapak, kakak, mbak, abang, mas, ayuk, dll. Dalam budaya Barat, memanggil nama saja mengindikasikan adanya kedekatan antara pihak yang satu dengan yang lainnya. Namun, jika hal ini terdengar oleh orang Indonesia tentu akan dicap sangat tidak sopan bahkan seseorang bisa menjadi marah jika hal tersebut dilakukan. Di dalam budaya Indonesia terdapat tata krama atau aturan kesopanan yang sering dilakukan oleh seseorang ketika ingin memanggil orang yang lebih tua atau baru dikenal. 
Pembubuhan kata $\mathrm{Bu}$, Pak, Mas, Mbak, Kakak, Abang harus disematkan ketika menuturkan nama mereka.

Contoh-contoh di atas perlu diketahui dan diajarkan oleh guru di dalam kelas. Guru dan peserta didik harus menyadari bahwa budaya memengaruhi cara orang berpikir dan cara mereka merespons. Qu dan Telzer (2017) menyebutkan sebuah negara yang memiliki satu budaya dominan akan mempengaruhi bagaimana masyarakatnya tumbuh dewasa, menanggapi, merespon dan menghargai hal-hal tertentu. Pola perilaku yang berbeda bisa saja akan membuat si penutur terkejut dan menganggap penutur bahasa lain kasar atau tidak sopan karena tidak sejalan dengan budaya mereka sendiri. Akibatnya, peserta didik yang ingin belajar bahasa Inggris harus menyadari berbagai budaya, tidak hanya budaya Indonesia dan Barat tetapi juga budaya lain di seluruh dunia guna meningkatkan kemampuan mereka dalam memahami dan berkomunikasi dengan baik.

Sehubungan dengan penjelasan di atas, ada beberapa poin yang ingin diteliti oleh penulis yaitu apakah guru sudah mengetahui peran penting budaya dalam pembelajaran bahasa Inggris sebagai bahasa asing, bagaimana tanggapan guru terkait penerapan literasi budaya di dalam kelas, dan bagaimana cara guru menjelaskan perbedaan budaya Indonesia dan Barat yang siswa pelajari dalam kelas.

\section{Metode Penelitian}

Penelitian ini merupakan penelitian deskriptif kualitatif yang mendeskripsikan fenomena yang terjadi pada proses pembelajaran bahasa Inggris berkaitan dengan peran budaya yang ada di dalamnya.

Ada empat guru yang diwawancarai untuk mendapatkan informasi yang dibutuhkan oleh peneliti. Para narasumber tersebut berasal dari Sekolah Menengah Atas (SMA) Bengkulu Utara, salah satu kabupaten yang ada di Provinsi Bengkulu. Keempat guru tersebut berasal dari sekolah yang berbeda dan mewakili setiap kecamatan yang ada di Bengkulu Utara.

\section{Hasil dan Pembahasan}

\section{Peran penting literasi budaya dan penerapannya di dalam kelas bahasa Inggris}

Dari wawancara yang dilakukan oleh peneliti, guru telah menyadari bahwa budaya adalah salah satu kunci untuk mendukung keberhasilan siswa dalam belajar bahasa, terutama bahasa Inggris sebagai bahasa asing. Ada beberapa keuntungan yang didapat ketika guru melibatkan literasi budaya di kelas. Pertama, pembelajar bahasa dapat menjadi lebih sadar bahwa dalam menyapa orang, mengungkapkan rasa terima kasih, mengajukan permintaan, dan mengungkapkan setuju atau tidak setuju dengan seseorang yang berbeda budaya tidaklah sama. Sehingga, mereka mengetahui bahwa perilaku dan pola intonasi yang sesuai dalam komunitas bahasa mereka sendiri dapat dirasakan berbeda oleh anggota komunitas bahasa target. Kedua, jika seseorang menjadi melek budaya akan mudah untuk berkomunikasi, berinteraksi, dan memahami orang lain dari budaya itu dengan lancar dan benar. Sementara jika seseorang buta akan budaya tentu akan menyebabkan kegagalan dalam memahami makna dari percakapan yang dilakukan contohnya ekspresi idiomatik, lelucon, dan penuturan nama. Ketiga, literasi budaya dapat memotivasi siswa dalam proses belajar, serta membantu siswa mengamati persamaan dan perbedaan yang ada di antara berbagai kelompok budaya.

Dari hasil pengamatan yang dilakukan, dapat dilihat juga bahwa guru menunjukkan antusiasme mereka untuk membuat siswa terlibat dalam proses belajar mengajarkan bahasa Inggris dengan menyelipkan kandungan budaya pada bahasa target. Beberapa aspek budaya dapat dimasukkan dengan cara mengembangkan pemahaman peserta didik, meningkatkan 
Volume 1, Nomor 2, Juli 2019

ISSN 2655-3031 (P), 2655-7851 (O)

perspektif yang dimiliki dan meningkatkan toleransi dalam melihat budaya yang berbeda. Dalam hal ini, kesadaran budaya dapat diperoleh dari pengembangan rasa batin yang dilakukan secara bertahap dari kesetaraan budaya yang didapat oleh peserta didik, sehingga dapat meningkatkan pemahaman tentang budaya sendiri dan orang lain, serta dapat mengetahui bagaimana budaya bisa terhubung dan berbeda. Seperti yang disebutkan oleh Frank (2013), peningkatan kesadaran budaya dapat membantu siswa untuk membuka pikiran mereka, meningkatkan toleransi dan meningkatkan empati dan kepekaan budaya.

Para guru juga menyebutkan bahwa dengan memperkuat kesadaran budaya siswa dapat meningkatkan kompetensi komunikatif budaya antar siswa, yaitu pengetahuan, kesadaran dan pemahaman tentang hubungan (kesamaan dan perbedaan khas) antara tempat asal dan tempat komunitas bahasa target. Peran guru dalam memperluas pengalaman pribadi peserta didik tentang bahasa dari budaya sumber ke budaya target, dan kemudian ke bahasa dan latar belakang budaya orang lain tampak begitu berharga. Selain itu, guru juga berpendapat bahwa keragaman budaya yang diajarkan di dalam kelas harus ditanggpi dan dijelaskan secara kritis guna mengembangkan literasi budaya peserta didik.

\section{Pengenalan literasi budaya di dalam kelas bahasa Inggris}

Ada banyak cara yang dapat digunakan oleh guru untuk mengajarkan literasi budaya di dalam kelas menurut Peterson dan Coltrance (2003), seperti:

1. Penggunaan bahan otentik

Guru dapat menggunakan pamflet, siaran berita, situs web, foto, majalah, koran, menu restoran, brosur perjalanan, dan bahan cetak lainnya dalam mengajarkan budaya. Guru dapat melibatkan siswa dalam diskusi tentang norma-norma budaya yang diwakili dalam contoh tersebut, misalnya menonton film yang memiliki konten budaya berbeda.
Topik diskusi mungkin termasuk perilaku nonverbal (misalnya jarak fisik antara pembicara, gerakan, kontak mata, dan peran sosial).

\section{Amsal}

Siswa dapat berdiskusi mengenai peribahasa umum dalam bahasa target dan dapat fokus pada bagaimana peribahasa itu berbeda atau mirip dengan peribahasa pada latar belakang budaya siswa. Misalnya peribahasa sedia payung sebelum hujan yang berarti seseorang harus berhati-hati atau mengantisipasi sebelum suatu kejadian buruk akan terjadi. Dalam budaya barat juga terdapat peribahasa yang memiliki arti serupa namun dengan penyampaian yang berbeda, yaitu make a hay while the sun shines. Karena di budaya barat memiliki empat musim maka para petani harus bersiaga untuk membuat jerami selagi musim panas. Sedangkan di Indonesia membuat peribahasa hujan karena Indonesia hanya memiliki dua musim, yaitu musim panas dan musim hujan. Jadi, kedua peribahasa tersebut memiliki arti yang sama namun didapatkan dari latar belakang budaya yang berbeda.

3. Role-play

Dalam bermain peran, siswa dapat melakukan miskomunikasi yang didasarkan pada perbedaan budaya. Misalnya, bagaimana cara mengatasi kelompok orang yang berbeda dalam budaya target, seperti orang dengan usia yang sama dan orang yang lebih tua, siswa dapat berperan dalam situasi di mana ucapan yang tidak tepat digunakan di suatu konteks budaya. Siswa lain mencoba mengamati permainan ini dan mengidentifikasi alasan miskomunikasi yang dapat terjadi

4. Siswa sebagai sumber budaya

Pertukaran siswa, siswa imigran, atau siswa yang berbicara bahasa target (bahasa Inggris) di rumah dapat diundang ke kelas sebagai penutur asli. Siswa-siswa ini dapat berbagi wawasan otentik ke dalam kehidupan rumah dan budaya penutur asli bahasa tersebut.

5. Studi etnografi 
Volume 1, Nomor 2, Juli 2019

Salah satu cara yang efektif bagi siswa untuk belajar tentang bahasa dan budaya target adalah dengan menyuruh siswa mencari informasi dengan melakukan wawancara etnografi dengan penutur asli di komunitas, yang kemudian direkam di buku catatan atau di kaset audio atau kaset video.

6. Literatur

Teks sastra sering berisi informasi budaya dan membangkitkan reaksi yang mengesankan bagi pembaca. Teks yang dipilih dengan cermat untuk kelompok siswa tertentu dan dengan tujuan yang tepat dapat membantu siswa memperoleh wawasan tentang suatu budaya.

Dari keenam poin ini, guru bahasa Inggris di wilayah Bengkulu Utara lebih cenderung kepada penggunaan buku teks dan bahan otentik. Menurut para guru, pengenalan literasi budaya dapat diajarkan melalui media ajar seperti buku teks karena buku teks sering diperhitungkan sebagai sumber utama proses belajar mengajar di dalam kelas. Isi buku teks dapat memiliki pengaruh besar pada tahap literasi budaya di sekolah. Selain itu, buku teks dapat digunakan sebagai media untuk mencapai tujuan pengajaran, memandu siswa belajar di sekolah dan di rumah, serta membantu persiapan guru sebelum proses pembelajaran berlangsung seperti dalam menyiapkan bahan, dalam memilih tugas, memanajemen kelas, dan juga mempunyai peran penting dalam penyebaran budaya. Dengan demikian, media ini dapat digunakan sebagai alat untuk mengajarkan literasi budaya.

\section{Tanggapan guru terhadap buku teks sekolah}

Sebagian besar buku pelajaran bahasa Inggris di Indonesia tidak hanya mengandung budaya Barat saja, akan tetapi juga ada budaya lain di luar Indonesia, seperti Jepang, Arab, Malaysia, Inggris, Amerika, Korea, dan sebagainya. Dehbozorgi, Amalsaleh, dan Kafipour (2017)) membagi budaya menjadi tiga jenis, yaitu budaya dari bahasa sumber, yaitu
ISSN 2655-3031 (P), 2655-7851 (O)

Indonesia; budaya target yang termasuk dalam bahasa target, yaitu, Inggris dan Amerika; dan budaya target internasional yang tidak termasuk dalam budaya sumber atau budaya target, contohnya Malaysia, Jepang, Arab, dan Korea.

Memiliki pengetahuan tentang
berbagai budaya memang dapat meningkatkan kompetensi siswa dalam berkomunikasi dengan orang lain di luar negara mereka dan membantu pembelajar bahasa memandang dunia dari perspektif yang berbeda. Namun, ternyata ada masalah yang diperdebatkan tentang porsi budaya yang harus dimasukkan ke dalam buku teks bahasa Inggris ini. Sebagian besar guru berpendapat bahwa perlu menempatkan porsi yang lebih besar pada budaya sumber daripada budaya target. Ini juga didukung oleh Cakir (2012), bahwa setiap orang memandang dunia dengan bahasa asli mereka sendiri yang berarti bahwa akan sangat mudah bagi pelajar untuk belajar bahasa target dengan menggunakan bahan otentik yang berasal dari budaya sumber. Dengan memberikan bagian yang lebih menonjol pada budaya barat dapat membahayakan budaya asli sehingga akan ada kecenderungan peserta didik untuk mengikuti budaya target dan melupakan budaya sumber. Sebaliknya, Turkan dan Celik (2007) menjelaskan bahwa budaya target harus dieksplorasi dan diintegrasikan lebih ke peserta didik pembelajar bahasa Asing karena akan meningkatkan kompetensi komunikatif siswa dalam bahasa Inggris. Sercu, Garcia, dan Casto (2005) menambahkan beberapa tujuan membiasakan peserta didik dengan budaya bahasa target seperti di bawah ini:

1. Meningkatkan pengetahuan siswa tentang dunia dan komunitas asing;

2. Mempromosikan sikap hormat dan toleransi;

3. Membina refleksi atas budaya sendiri.

Menanggapi masalah di atas, sebenarnya masalah tentang konten budaya tidak pada porsi keberadaan jenis budaya, tetapi dalam nilai yang dibawa oleh konten 
budaya tersebut. Nilai budaya itu harus sesuai dengan tujuan pendidikan nasional guna meningkatkan literasi budaya peserta didik. Konten budaya tidak boleh bertentangan dengan karakter nasional Indonesia. Meskipun diyakini bahwa budaya sumber memiliki persentase tinggi, pentingnya budaya target tidak dapat diabaikan. Keduanya sangat penting untuk meningkatkan kompetensi siswa dalam berkomunikasi dalam bahasa Inggris.

Tentunya, para guru tidak hanya harus mengandalkan buku teks untuk mendapatkan pengetahuan budaya. Ada banyak media pembelajaran lain yang bisa digunakan untuk mengenalkan literasi budaya kepada siswa di dalam kelas bahasa seperti yang disebutkan oleh Peterson dan Coltrane (2003).

\section{Simpulan}

Literasi budaya harus diajarkan di kelas pembelajaran bahasa asing karena akan ada beberapa keuntungan yang didapat guru dan siswa, seperti meningkatkan perspektif siswa dalam melihat sesuatu yang tidak biasa bagi dilihat ataupun dirasakan. Siswa juga dapat menghormati sudut pandang orang lain dalam berdebat, menjelaskan atau memberikan pendapat.

Ada banyak cara yang dapat digunakan untuk meningkatkan literasi budaya siswa contohnya penggunaan bahan otentik, amsal, role-play, pertukaran siswa, studi etnografi, dan literatur. Buku teks bisa juga menjadi salah satu media yang dapat digunakan untuk mengenalkan literasi budaya. Namun, guru harus memilih dengan tepat agar keseimbangan budaya terjaga guna mendukung siswa dalam memahami multi-budaya yang ada di sekitar. Setiap kategori budaya (budaya sumber, budaya target,dan budaya internasional) dapat membantu mereka meningkatkan kompetensi komunikatif mereka, misalnya: penggunaan budaya sumber dapat membantu peserta didik mengadopsi materi bahasa, menyesuaikannya dengan konteks pembelajaran bahasa sumber, dan mengetahui tujuan berkomunikasi; budaya target membantu menghindari miskomunikasi dan kegagalan pragmatis; budaya target internasional akan memudahkan siswa berkomunikasi dan berinteraksi dengan menggunakan bahasa Inggris sebagai lingua franca. Singkatnya, dapat disimpulkan bahwa literasi budaya harus diajarkan kepada siswa untuk menggali lebih dalam potensi bahasa mereka dalam belajar bahasa Inggris sebagai bahasa asing.

\section{Daftar Pustaka}

Assemi, A., Saleh, S., Asayeshh, M. E., \& Janfaza, E. (2012). Culture within Language. International Conference on Language, Medias and Culture, 33, 78-82.

Cakir, I. (2012). Developing Cultural Awareness in Foreign Language Teaching. Turkish Online Journal of Distance Education, 5(3), 154-161. https://doi.org/10.5539/elt.v5n3p95

Dehbozorgi, M., Amalsaleh, E., \& Kafipour, R. (2017). Cultural categories in three mainstream EFL textbooks in Iran: A case study of Top Notch, American English Files, and Four Corners. International Journal of Research Studies in Education, 7(3).

https://doi.org/10.5861/ijrse.2017.1816

Frank, J. (2013). Raising cultural awareness in the Language classroom. Eric, 51(4), 2-11. Retrieved from http://https//eric.ed.gov/?id=EJ1020809

Giosa, V. D. (2009). The Cultural Management of Leadership. 19, 167-191.

Hirsch, E. D. (1984). Cultural Literacy. National Adult Literacy Project. https://doi.org/10.1158/1535-7163.mct-160142

Peterson, E., \& Coltrance, B. (2003). Culture in Second Language Teaching. (December).

Qu, Y., \& Telzer, E. H. (2017). Cultural Differences and Similarities in Beliefs, Practices, and Neural Mechanisms of Emotion Regulation. Cultural Diversity and Ethnic Minority Psychology, 23(1), 30-44.

https://doi.org/10.1080/13698036.2014.98 0638

Sercu, L., Garcia, D.L.C.M., \& Casto, P. (2005). 
Culture learning from a constructivist perspective. An investigation of spanish foreign language teachers' views. Language and Education, 19(6), 483-495. https://doi.org/10.1080/095007805086686 99

Spencer-oatey, H. (2012). What is Culture? A Compilation of Quotations. GlobalPAD Core Concepts., 1-22. Retrieved from https://warwick.ac.uk/fac/soc/al/globalpad/ openhouse/interculturalskills/global_pad_what is_culture.pdf

Turkan, S., \& Celik, S. (2007). Integrating Culture into EFL Texts and Classrooms: Suggested Lesson Plans. Novitas-ROYAL, 1(1), 18-33. 